\title{
Economic Benefits of Medicinal Plants for Communities Around the Mount Halimun Salak National Park, West Java, Indonesia
}

\author{
Yelin Adalina $^{1}$ and Meilina Pudjiani ${ }^{2}$ \\ \{yelinadalina@yahoo.com ${ }^{1}$, meilina.p25@gmail.com ${ }^{2}$ \} \\ Forest Research and Development Center; Jl. Gunung Batu No 5, Bogor 16610, West Java, Indonesia ${ }^{1}$, \\ Business School IPB University, Indonesia ${ }^{2}$
}

\begin{abstract}
Communities in the surrounding area of Mount Halimun Salak National Park (MHSNP) actively involved in maintaining the preservation. One way is through the use of medicinal plants in the Utilization Zone of MHSNP. The purpose of this study is to determine the economic benefits of medicinal plants through agroforestry for the community in the area. The research was carried out in Gunung Malang Village, SubDistrict Cikidang, Sukabumi Regency.The survey method was conducted using interviews with 30 respondents, was selected purposively. The vegetation data obtained in from the analysis the Importance Value index (IVI). The results of IVI, there are 8 types of vegetation at the tree level. Rubber plants with IVI of $181.84 \%$, density of 875 trees/ha and Schima wallichii Korth with IVI of $19.39 \%$, density of 50 trees/ha are the dominant species. Most respondents (62.5\%) planted cardamom and ginger. Under tree stands of 250 trees/ha, respondents' income from cardamom was USD 210/ha/year and ginger was USD 208/ha/year. The number of trees planted did not correlate significantly with the production of medicinal plants $(\mathrm{p}<0.05)$. Community involvement in the utilization of medicinal plants in MHSNP has significant effects in increasing the income of forest communities. The concept of green marketing is supported by internal and external components, respondents influence internal components as production while suppliers are on external components.
\end{abstract}

Keywords: Communities around forest, income, medicinal plants, Mount Halimun Salak National Park

\section{Introduction}

In 2003 based on Minister of Forestry Decree No.175 / kpts-II / 2003 Mount Halimun National Park (MHNP) was expanded from $\pm 40,000$ hectares (ha) to $\pm 113,357$ ha into the Mount Halimun Salak National Park (MHSNP) by changing the function of the Forest Production and Protection Forests that were previously managed by Perum Perhutani. The MHSNP work area is located in 28 sub-districts in three districts Bogor, Sukabumi, and Lebak. One hundred eight villages are partly or wholly located within and directly adjacent to the MHSNP area1 [1]. 
The establishment of conservation area management units often leads to conflicts between the government and the people who have already lived or conducted activities in the area [2]. Neither the various problems in the management of MHSNP include the encroachment of the area for various interests, namely: land use for rubber plantations, settlements, agricultural land, and gold mining without permission [2];[1]. Various land uses in MHSNP encourage deforestation, which causes damage to habitats and ecosystems in the conservation area.

Various forms of natural resource utilization within the MHSNP area have generally taken place since before the area's designation as a national park [1]. These problems indicate the community's high dependence on conservation areas or forest resources [2]. They often correlate with the community's low level of welfare around the national park [3]. On the one hand, the government must optimally guarantee the community's life and welfare in and around conservation areas. However, on the other hand, the government must limit people's access to conservation areas to maintain their conservation functions [2].

Communities around forests have an attachment to forest resources in supporting their economic household needs [4]. Conservation areas have a variety of benefits to meet the various needs of people around the forest, both direct (tangible) and indirect (intangible) benefits [5]. One of the forest resources with a comparative advantage with communities around the forest is non-timber forest products (NTFPs). Non-wood forest products are proven to have an impact on increasing the income of communities around the forest.

Various studies related to the economic value of NTFPs include [4] that the value of NTFP utilization by communities around the forest in the KapuasKahayan KPHL is Rp 684.450.000/year from five types of NTFPs consisting of gum, honey, rattan, animal wild, firewood. The statement of Ulfa et al., (219) that the total value of the NTFP Bukit Dua belas National Park benefits is Rp 1.042.030.000/year. The value of the benefits of grasses in the MHSNP area as animal feed utilized by the Kasepuhan Sinar Formal community is an average of Rp 450.000/month/respondent [7]. The contribution of NTFPs is around $25.16 \%$ of the income of each family head of the Bukaka Village community [8]. The benefits of NTFPs can increase the income of local people in efforts to reduce poverty, and it is also beneficial for the conservation of forest resources [9]. Utilization of NTFPs can help people obtain more diverse sources of livelihoods without destroying forests [10].

To preserve the forest will be difficult to realize without the community's support and participation if it is not balanced with government efforts to improve the welfare of the community around the forest. Forest sustainability 
cannot be separated from communities' ecological, economic, and social conditions around the forest [11]. Community participation provides a better impact in managing sustainable forests in the future [12]. Therefore, we need a form of interaction between the community and the management so that the national park's function remains optimal, and the welfare of the community is met, among others, through the utilization of NTFPs [7]. As mentioned in Permenhut No P.19 of 2009 [13], forest management needs to be directed as a producer of NTFPs that can open activities and income for local communities by considering ecological factors. Identifying forest resources, their use by the community, and their economic value is one of the essential aspects that can support the preparation of programs and policies in management [4]. Through the MHSNP economic valuation approach, the estimated value of the benefits will be known quantitatively and measurably, which can be used as a basis for stakeholders in making decisions in determining sustainable management of the area.

This study aims to determine the characteristics of individual communities around MHSNP, identify types, and determine the economic benefits of NTFPs for medicinal flora in the MHSNP area. The utilization of NTFPs for medicinal plants in the MHSNP area is one alternative that can accommodate the economy of the community around the forest. Therefore, knowing the value of medicinal plants' economic benefits in the MHSNP area needs to be done so that the benefits can be understood and understood by all stakeholders in managing MHSNP.

\section{Methods}

\subsection{The general condition of research location}

The study was conducted in Gunung Malang Village, Cimantaja Resort. Region III Section Sukabumi, Balai Halimun Salak National Park. Administratively, the research site is located in Cikidang Subdistrict, Sukabumi Regency, West Java Province, Indonesia (Figure 1). Geographically it is located at $106^{\circ} 33$ '10 "- 106 37'45" East Longitude and 06 49'40 "- 06 53'15" South Latitude. According to Schmidt and Ferguson [14], the type of rainfall with an average rainfall of $4000-5000 \mathrm{~mm}$ per year. The average temperature is $30^{\circ} \mathrm{C}$, with the lowest temperature is $20^{\circ} \mathrm{C}$, and the highest temperature is $30^{\circ} \mathrm{C}$, and the average humidity is $80 \%$. The place's height ranges from $500-1,462 \mathrm{~m}$ above sea level, with undulating, hilly, and mountainous topography. The slope ranges from $15-45 \%$. Soil type is Latosol Chocolate, Andosol Chocolate, and Regosol Chocolate. The area of the Cimantaja Resort area is 2988.34 ha, which 
consists of the area of state forests (national parks) located in three villages Cikiray Village, Mekarnangka Village, and Gunung Malang Village. The area of MHSNP in Gunung Malang Village is 315,142 ha and has 1,114,774 ha with a population of 4,313 people (1,178 households), and around $70 \%$ work as farmers [15].

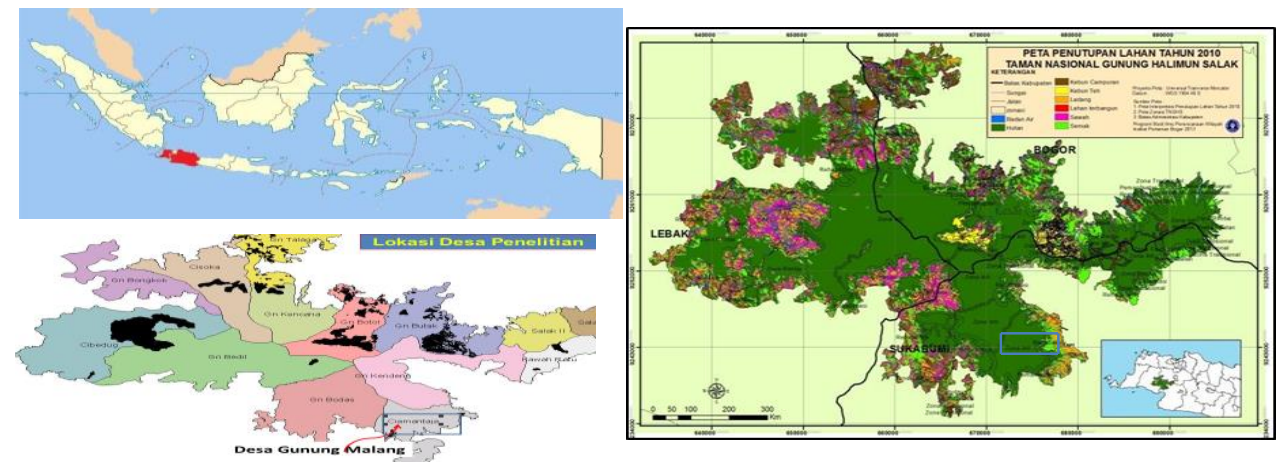

Figure 1. The research location was Gunung Malang Village, Cimantaja Resort, Mount Halimun Salak National Park, West Java Province, Indonesia

\subsection{Vegetation analysis}

Vegetation analysis material is the observation plot on community arable land in Gunung Malang Village, Cimantaja Resort, Mount Halimun Salak National Park, covering an area of 0.16 ha. The research methods used were surveys, observations, and interviews using questionnaires. Village selection in the study was conducted by purposive sampling. Random respondent selection and the number of respondents interviewed was 30 respondents.

Vegetation measurement of 4 plots by plot path. Vegetation analysis was performed at each level of tree growth with classification: seedlings $(2 \times 2 \mathrm{~m}$ plots), sapling (5x5 m plots); pole (10x10 m plots), and trees (20x20 m plots). The collected data was analyzed to determine individual density, species frequency, and dominance of the three parameters obtained essential values that can be used to know the dominant types.

Analysis of the economic benefits of NTFPs for medicinal plants is carried out through the value of direct use, which is the result of NTFPs for medicinal plants, which are utilized directly by the community around the TNGHS area. The valuation method used is through a market price approach.

\subsection{Data analysis}

Coding data perform data analysis. The data obtained is processed by tabulating and presented descriptively and tabulated. Vegetation data were 
analyzed to determine the Importance Value Index (INP) based on species density, dominance, and frequency based on the formula [16].

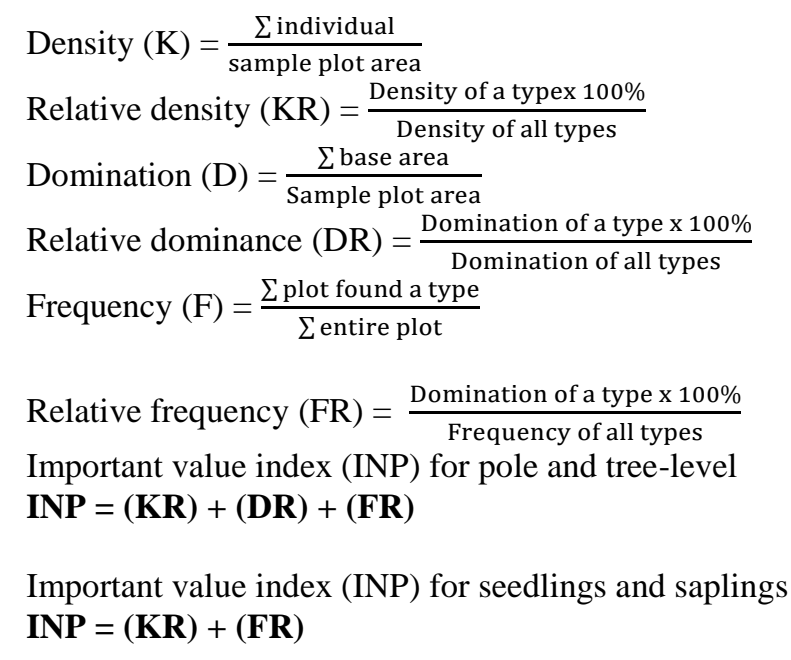

The economic benefits of medicinal plants are analyzed descriptively. The value of medicinal plants' direct benefits by calculating the average usage each year (type/respondent/year) and the economic value of medicinal plants ( $\mathrm{Rp} /$ year) with the formula:

$\mathrm{XPTO}=\mathrm{TPTO} / \sum \mathrm{RT}$

$\mathrm{NETO}=\mathrm{HBP} \times \mathrm{XPTO} \times \sum \mathrm{RT}$

XPTO : Average taking of medicinal plants (type/respondent/year)

TPTO : Total uptake of medicinal plants (type/year)

$\sum \mathrm{RT} \quad$ : Number of respondent households

NETO : The economic value of medicinal plants (Rp/year)

HBP : Cost of treatment (Rp/respondent)

\section{Results and Discussion}

\subsection{Individual characteristics of the community around MHSNP in Gunung Malang Village}

The community's socio-economic condition is one of the most important aspects to be considered in the management of national parks [17]. There is a close relationship between the forest's existence and the socio-economic conditions of the communities around the forest and environmental conditions (biophysical) [11]. By knowing the socio-economic community's conditions around the forest so that efforts can be determined in the management of 
GHSNP and programs that can be applied to communities in the area around MHSNP [18].

The identification of individual respondents based on gender, religion, and ethnicity of the 30 respondents interviewed consisted of 24 male respondents $(80 \%)$ and six female respondents (20\%). Overall, respondents were Muslim and Sundanese. The age of the respondents varied between 29 to 72 years (Table 1). Based on the classification of age classes [19], most respondents $(80 \%)$ belong to productive age (above 15 years to 55 years) and $20 \%$ of respondents at the non-productive age level (above 55 years). Data shows that most respondents have the potential to move to the maximum, in various efforts to meet the needs of their families. Then this potential productive age needs to be utilized and possible in the management of MHSNP [18].

Most of the respondents with formal education levels were classified as low $(56.67 \%)$, that is, only elementary education (SD) and as many as $43.33 \%$ of respondents with higher education levels (SLTP-SLTA). Formal education level indicators show that the quality of human resources around the MHSNP area is mostly in the low category. The low level of education makes people have no choice but to work as farmers [18]. The level of formal education plays an essential role in shaping the people's mindset in acting and is one indicator to determine farmers' ability to accept innovations [18]; [20].

Data shows that most respondents $(46.67 \%)$ had never attended nonformal education in the low category. As many as $46.67 \%$ had attended nonformal education in the medium category and $6.66 \%$ in the high category (Table 1). Rinawati [21] suggested that the knowledge and information obtained through non-formal education can change society's mindset and decisionmaking. The empowerment process went expedited if the non-formal education provided is appropriate and related to the profession and local resources [22].

Data shows that all respondents (100\%) are indigenous people who have occupied the location since birth. This data is definite support for the programs that will be implemented in the management of GHSNP. Indigenous people who have long lived have an attachment to the area they occupy and the use of surrounding land resources [23].

According to Mulyono [24], the number of family members in each respondent's household is a description of labor availability, dependents on family life, and the amount of family income. Data shows that, when viewed from the number of dependents of the family, $50 \%$ of the head of the family bear three lives, which means that one head of the farmer's family must work to meet four family members' living needs (Table 1). Pujowati [25] suggested that as many as four family members per head of household are a potential source of labor and can reduce the burden on the head of the family if utilized 
optimally. The number of family dependents will affect the head of the family's enthusiasm and creativity to meet the economic needs of his family [26].

Most respondents work as farmers by $60 \%, 40 \%$ of respondents have varied livelihoods (Table 1). In addition to having a primary job, most respondents have side-income to meet household needs. A total of 22 respondents or $73.33 \%$ of the total respondents have side livelihoods (Table 1). However, many respondents only rely on their income from agricultural products as their primary occupation and do not have side jobs, namely as many as eight people or $26.67 \%$. Therefore, it is necessary to develop skills in order to increase community income.

Most $(46.67 \%)$ of respondents have land $<0.5$ ha and as many as ten respondents with an area of land $>1.0$ ha. The average area of respondent's arable land is 0.80 ha (Table 1). There is a real relationship between land ownership and socio-economic aspects. The morefull the community's land ownership, the more prosperous the community's socio-economic conditions [23].

In Table 1, it can be seen that nine respondents (30\%) did not own land owned and as many as $70 \%$ of respondents owned land either in the form of gardens or rice fields. Therefore, farmers who do not own the land use land in the GHSNP area as a source of income to support the household needs of respondents. Subarna [27] argues that the narrow area of owned land causes farmers' income to be meager so that to meet the needs of their families to expand their farming business through arable in the forest that borders his village.

Most of the respondents $(60.00 \%)$ are farmers working on state land whose management is in the Mount Halimun Salak National Park Office (Table 1). Generally, smallholders in the national park area are former PHBM farmers during the management period by Perum Perhutani. Communities are required to plant forestry plants on arable lands such as puspa (Schima wallichii), tisuk (Hibiscus macrophyllusroxb), and huru (Machilus rimota) [18]. As the population increases, the level of dependence on land for farming in the national park area by former PHBM participants during the management of Perum Perhutani increases while the availability of land does not increase [28].

Based on the calculation of the value interval equation Supranto [29] the respondents' income is below Rp1,000,000 in the low category. Data shows nine respondents or $30 \%$ with low-income levels, under Rp1,000,000/month. Most respondents (53.30\%) have a total income of between Rp1,000,000 to Rp1,500,000 /month with a moderate income level category. The average

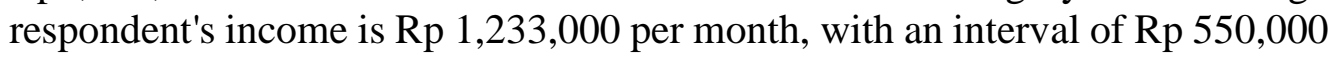
to $\mathrm{Rp} 3,000,000$ (Table 1). When referring to the regional minimum wage 
(UMR), respondents' average level of income is below the UMR of West Java province in Sukabumi Regency in 2017, which is Rp2,376,000. The respondent's income from agricultural products is strongly influenced by weather factors and market factors so that the results are uncertain. The market for agricultural products is also controlled by middlemen so that most farmers do not have a high bargaining position.

Table 1. Individual characteristics

\begin{tabular}{|c|c|c|c|}
\hline Characteristics of respondents & Classification & $\begin{array}{l}\text { Number of } \\
\text { respondents }\end{array}$ & $\begin{array}{l}\text { Percent } \\
(\%)\end{array}$ \\
\hline \multirow[t]{2}{*}{ Gender } & Male & 24 & 80.00 \\
\hline & Female & 6 & 20.00 \\
\hline Ethnic & Sundanese & 30 & 100.00 \\
\hline Religion & Islam & 30 & 100.00 \\
\hline \multirow[t]{2}{*}{ Age group (people) } & Productive age (>15tahun) & 24 & 80.00 \\
\hline & Non-productive age (> 56 tahun) & 6 & 20.00 \\
\hline \multirow[t]{2}{*}{ Levels of formal education } & $\begin{array}{l}\text { not completed in primary school- } \\
\text { graduated elementary school (low) }\end{array}$ & 17 & 56.67 \\
\hline & $\begin{array}{l}\text { Junior High School (SLTP)-High } \\
\text { School (SLTA) (moderate) }\end{array}$ & 13 & 43.33 \\
\hline \multirow[t]{3}{*}{ Level of non-formal education } & Never (low) & 14 & 46.67 \\
\hline & 1-3 times (moderate) & 14 & 46.67 \\
\hline & $>3$ times (high) & 2 & 6.66 \\
\hline Residence status & Native & 30 & 100.00 \\
\hline \multirow{4}{*}{$\begin{array}{l}\text { Number of family members } \\
\text { (people) }\end{array}$} & < 4 (low category) & 7 & 23.33 \\
\hline & 4 (moderate category) & 12 & 40.00 \\
\hline & $>4$ (high category) & 11 & 36.67 \\
\hline & $\leq 2$ (low category) & 11 & 36.67 \\
\hline \multirow[t]{2}{*}{ Number of dependents (people) } & 3 (moderate category) & 15 & 50.00 \\
\hline & $\geq 4$ (high category) & 4 & 13.33 \\
\hline \multirow[t]{3}{*}{ Main occupation (people) } & Farmers & 18 & 60.00 \\
\hline & Labor & 9 & 30.00 \\
\hline & Others & 3 & 10.00 \\
\hline \multirow[t]{2}{*}{ Side jobs (people) } & Farmers & 2 & 6.66 \\
\hline & Labor & 7 & 23.33 \\
\hline The area of arable land in the & Others & 13 & 43.34 \\
\hline \multirow[t]{2}{*}{ MNGHS area (ha) } & There is no & 8 & 26.67 \\
\hline & Landless (low) & 9 & 30.00 \\
\hline \multirow[t]{2}{*}{ Land area owned (ha) } & $\leq 0,25$ ha (moderate) & 11 & 36.67 \\
\hline & $>0,25$ ha (high) & 10 & 33.33 \\
\hline The area of arable land in the & $\leq 0,5$ ha (moderate) & 22 & 73.33 \\
\hline MNGHS area (ha) & $>0,5$ ha (high) & 8 & 26.67 \\
\hline Income level from main and side & $<$ Rp 1000 (low) & 9 & 30.00 \\
\hline \multirow{2}{*}{ jobs $(\operatorname{Rpx} 1.000)$} & Rp $1000-1.500$ (moderate) & 16 & 53.30 \\
\hline & $>$ Rp 1.500 (high) & 5 & 16.70 \\
\hline
\end{tabular}

\subsection{Vegetation Analysis}

Types of medicinal plants planted by the people of Gunung Malang Village include kapol, kaempferia galanga, ginger, turmeric, galangal, and 
lempuyang. Most people who cultivate land in the MHSNP area planted Kapol with agroforestry patterns understands combined with forestry plants, MPTS (Multy Purpose Tree Species), and plantation crops.

The calculation results of the Importance Value Index (INP) show that there are eight species of plants at the tree level found in community arable land in the MHSNP area, among others, rubber (Hevea brasiliensis), hanjuang (Cordyline fruticose), johar (Senna siamea), suren (Toona sinensis), jackfruit (Artocarpus heterophyllus), mahogany (Swietenia mahagoni), pete (Parkia speciosa Hassk) and puspa (Schima wallichii). Most people plant rubber $(H$. brasiliensis) on their arable land in the MHSNP area. This is because of mentoring by the NGOs, with the LATIN program, the community wanted the type of rubber plant to rehabilitate the area. The reason for choosing this type is because it is a source of daily income in the future in supporting the household economy. The income from the results of rubber taps on community cultivated land in the MHSNP area in Pangradin Village, Jasinga District, is Rp525,000 Rp1,500,000 with an average contribution of $60.71 \%$ to household income [30]. Although it provides a significant contribution to the household income of farmers, this plant is exotic. Exotic plants can threaten local native species [31].

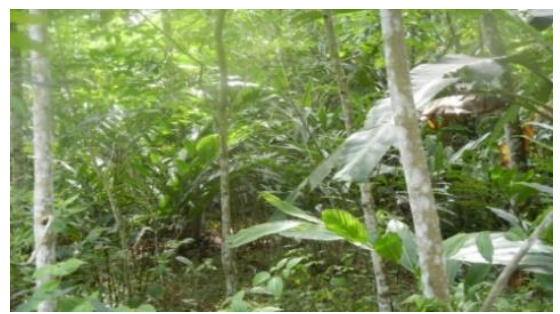

Figure 2. Kapol plants on community arable land in the MHSNP area in Gunung Malang Village

Rubber plants (Hevea brasiliensis) are the most dominant species at tree level with INP $181.84 \%$, the relative density of $70 \%$, and species density of 875 individuals/ha. They were then followed by Hanjuang plants with INP $34.61 \%$, 100 individuals/ha, and a relative density of $8 \%$. Data shows that mahogany plants with an INP of $21.39 \%$, the relative density of $6 \%$ and species density of 75 individuals/ha and puspa plants with an INP of $19.39 \%$, the relative density of $4 \%$ and species density of 50 individuals/ha. This shows that rehabilitation programs have been carried out on community cultivated land with forest species.

There are six types of plants at the pole level, namely rubber $(H$. brasiliensis), durian (D. zibethinus), banana ( $P$. speciosa Hassk), jackfruit (A. heterophyllus), manii (M. emini Engl) and pest (M. rimota). The most dominant species at the pole level are rubber plants with an INP of $228.31 \%$, a relative density of $83.87 \%$, and 2600 species/ha. The manager of MHSNP gave policy 
to the community who worked on the land before the expansion of the MHSNP area since Perum Perhutani managed it. Most respondents worked on arable land in the MHSNP area in the form of gardens since before expanding the area [7].

Types of plants that dominate at the sapling level are huru (M. rimota) with $100 \%$ INP, 50\% relative density, and 1,600 individual density/ha. There are two types of plants at the seedling level, namely kapol and kaempferia galanga plants. Types of plants that dominated at the seedling level were kapol plants with INP $121.21 \%$, the relative density of $54.54 \%$, and 75,000 individuals/ha.

Table 2. Importance Value Index for vegetation types in the MSNP Cimantaja Resort area

\begin{tabular}{llccccc}
\hline $\begin{array}{l}\text { Classific } \\
\text { ation }\end{array}$ & \multicolumn{1}{c}{ Type of plant } & $\begin{array}{c}\text { K (individuls } \\
\text { /ha) }\end{array}$ & $\begin{array}{c}\text { KR } \\
(\%)\end{array}$ & $\begin{array}{c}\text { DR } \\
(\%)\end{array}$ & $\begin{array}{c}\text { FR } \\
(\%)\end{array}$ & INP (\%) \\
\hline Tree & Rubber (Hevea brasiliensis) & 875 & 70.00 & 88.76 & 23.07 & 181.84 \\
level & Hanjuang (Cordyline fruticose) & 100 & 8.00 & 11.23 & 15.39 & 34.61 \\
& Johar (Senna siamea) & 25 & 2.00 & 0 & 7.69 & 9.69 \\
& Suren (Toona sinensis) & 25 & 2.00 & 0 & 7.69 & 9.69 \\
& Jackfruit (Artocarpus & 50 & 4.00 & 0 & 7.69 & 11.69 \\
& heterophyllus) & 75 & 6.00 & 0 & 15.39 & 21.39 \\
& Mahogany (Swietenia mahagoni) & 50 & 4.00 & 0 & 7.69 & 11.69 \\
& Pete (Parkia speciose Hassk) & 50 & 4.00 & 0 & 15.39 & 19.39 \\
Pole & Puspa (Schima walici) & & & & & \\
level & Rubber (Hevea brasiliensis) & 2600 & 83.85 & 100.0 & 44.45 & 228.30 \\
& Durian (Durio zibethinus) & 100 & 3.23 & 0 & 11.11 & 14.34 \\
& Pete (Parkia speciose Hassk) & 100 & 3.23 & 0 & 11.11 & 14.34 \\
& Jackfruit (Artocarpus & 100 & 3.23 & 0 & 11.11 & 14.34 \\
& heterophyllus) & 100 & 3.23 & 0 & 11.11 & 14.34 \\
& Manii (Maesopsis emini Engl) & 100 & 3.23 & 0 & 11.11 & 14.34 \\
Sapling & Huru (Machilus rimota) & & & 0 & & \\
level & Rubber (Hevea brasiliensis) & 1200 & 12.50 & - & 16.67 & 29.17 \\
& Manii (Maesopsis emini Engl) & 400 & 37.50 & - & 33.33 & 70.83 \\
& Huru (Machilus rimota) & 1600 & 50.00 & - & 50.00 & 100.00 \\
Seedling & Kapol (Amomum compactum) & 75000 & 54.54 & - & 66.67 & 121.21 \\
level & Kencur (Kaempferia galanga) & 62500 & 45.46 & - & 33.33 & 78.79 \\
\hline Note: KR & Relative density; DR = Relative dominance; FR & FRelative frequency; INP= Important value index
\end{tabular}

Table 3. Average height and diameter of the plant

\begin{tabular}{clccc}
\hline No & \multicolumn{1}{c}{ Types } & $\begin{array}{c}\text { Number of } \\
\text { plants }\end{array}$ & $\begin{array}{c}\text { Average } \\
\text { height }(\mathrm{m})\end{array}$ & $\begin{array}{c}\text { Average } \\
\text { diameter }(\mathrm{cm})\end{array}$ \\
\hline 1 & Rubber (Hevea brasiliensis) & 105 & 4.6 & 17.60 \\
2 & Manii (Maesopsis emini Engl) & 3 & 2.7 & 8.33 \\
3 & Johar (Senna siamea) & 2 & 6.8 & 24.00 \\
4 & Suren (Toona sinensis) & 3 & 6.7 & 30.00 \\
5 & Tisuk (Hibiscus macrophyllusroxb. Ex) & 3 & 6.3 & 17.67 \\
6 & Huru (Machilus rimota) & 10 & 2.2 & 7.00 \\
7 & Mahogany (Swietenia mahagoni) & 3 & 9.3 & 46.00 \\
8 & Sungkai (Peronema canescens Jack) & 1 & 4.0 & 13.00 \\
\hline
\end{tabular}




\begin{tabular}{clccc}
\hline 9 & Puspa (Schima walici) & 4 & 5.5 & 21.25 \\
10 & Jenjing (Paraserianthes falcataria) & 2 & 1.0 & 3.00 \\
11 & Durian (Durio zibethinus) & 5 & 2.8 & 7.67 \\
12 & Pete (Parkia speciose Hassk) & 5 & 4.3 & 18.50 \\
13 & Coffee (Coffea) & 2 & 1.8 & 4.50 \\
14 & Jackfruit (Artocarpus heterophyllus) & 7 & 2.8 & 20.90 \\
15 & Hanjuang (Cordyline fruticose) & 12 & 3.6 & 30.67 \\
\hline
\end{tabular}

To determine the condition of the stand-in assessing the success of planting in terms of several parameters, namely the number of stems/hectare, diameter, and plant height [32]. In Table 3, it can be seen that the height of rubber plants in Gunung Malang Resort Cimantaja Village ranges from 3.1 - 6.4 $\mathrm{m}$ with an average of $4.6 \mathrm{~m}$. The diameter of rubber plants ranged from $11.5-$ $23.60 \mathrm{~cm}$, with an average of $17.60 \mathrm{~cm}$. The average height of rubber plants in Gunung Malang village is lower than the average height of rubber plants found in the MHSNP area in Pangradin Village, with an average height of $10.6 \mathrm{~m}$ [30]. This is due to differences in plant age and environmental biophysical conditions such as altitude, soil conditions, temperature, and rainfall. Following the statement, Rusdiana \& Amalia [32] that plant growth is influenced by soil conditions, rainfall, and altitude.

\subsection{Value of Economic Benefits of Medicinal Plants}

\subsubsection{Respondents' income from medicinal plants in the MHSNP area}

The majority of people cultivate four plants grown on MHSNP arable land, turmeric, galangal, ginger, and cardamom. The results showed that most respondents $(62.5 \%)$ planted cardamom types and as much as $60.15 \%$ of respondents planted ginger. Most respondents chose these two types of plants because they have high selling points. The types of cardamom, kencur, ginger, and turmeric plants are of high interest to the community because they are fastgrowing, easy to obtain plant seeds do not require high costs/capital, easy to maintain, and natural marketing.

Problems faced by respondents are low selling prices, limited business capital for the costs of seeds, fertilizer, and planting. The growth of root rot or fungus sometimes attacks plants, and limited information on the types of crops that can be cultivated have high selling prices. Respondents sell their products to intermediaries so that they do not have a high bargaining position.

Respondents' income from medicinal plants varies. This income depends on the respondent's cropping pattern, the area of arable land managed, the type and amount of timber contained in arable land, and the type of medicinal plants cultivated. In Table 4, it can be seen that the highest income is obtained by combining the four types of medicinal plants authorized cardamom, ginger, 
turmeric, and galangal, with an income of $\mathrm{Rp} 11,633,000$ / ha. The data shows that the higher the number of perennials found in arable land in the MHSNP area, the lower the respondents' income. The analysis results show that if the number of perennials found in arable land is 563 trees/ha with one medicinal plant species cultivated is cardamom, with the production of 1.5 tons/ha, then the respondent's income from cardamom plants is $\mathrm{Rp} 10,500,000$.

However, if the number of tree plants is 1125 trees/ha, the cardamom production will be lower, and the respondent's income will be $\mathrm{Rp} 4,200,000$ / ha. Cardamom production from the results of this study is lower than the results of the study of Diniyati et al., (2014) with the number of cardamom production in Karyabakti Village of 2.5 tons/ha. Respondents' income from cardamom is higher than the three types of medicinal plants ginger, turmeric, and galangal. This study is in line with the research Diniyati and Achmad (2015) that cardamom plants contribute the most to the total income of smallholder forest farmers in the amount of $25.90 \%$.

If three types of medicinal plants are cultivated with a total of 1250 trees/ha. The income derived from ginger plants is $\mathrm{Rp} 3,750,000$, turmeric is $\mathrm{Rp}$ $1,500,000$, and galangal is $\operatorname{Rp} 3,750,000$ with a total income of $R p 9,000,000 /$ ha with the selling price of ginger Rp 5,000/kg, turmeric Rp 1,500/kg and galangal of Rp Rp 3,000/kg. This shows that the number of crop commodities cultivated is more profitable than one type of crop commodity. This study is in line with Achmad's research (2016) that farmers who adopt a mixed cropping pattern with four types of plants are wood, plantation, fruit, and medicinal plants will increase income by $27.39 \%$ compared to adopting three types of mixed plants namely wood, fruit, and drug.

Table 4. The number of plants and production of medicinal plants per hectare of arable land area in the village of Gunung Malang MHSNP

\begin{tabular}{|c|c|c|c|c|c|c|c|c|c|}
\hline \multirow[t]{2}{*}{ No } & \multirow{2}{*}{$\begin{array}{l}\text { Number } \\
\text { of plants } \\
\text { MPTS } \\
\text { /ha }\end{array}$} & \multirow{2}{*}{$\begin{array}{l}\text { Number } \\
\text { of } \\
\text { forestry } \\
\text { plants /ha }\end{array}$} & \multirow[t]{2}{*}{$\begin{array}{l}\text { Number } \\
\text { of rubber } \\
\text { plants /ha }\end{array}$} & \multirow{2}{*}{$\begin{array}{l}\text { The total } \\
\text { number of } \\
\text { plants /ha }\end{array}$} & \multicolumn{4}{|c|}{ Production of medicinal plants $\mathrm{kg} / \mathrm{ha} /$ years } & \multirow{2}{*}{$\begin{array}{l}\text { Income of } \\
\text { medicinal plants } \\
(\text { Rp x } \\
1.000 / \text { year/ha) }\end{array}$} \\
\hline & & & & & cardamom & ginger & turmeric & galangal & \\
\hline 1 & 136 & - & - & 136 & 187 & 468 & - & - & 3649 \\
\hline 2 & 94 & 156 & - & 250 & 450 & 625 & - & - & 6275 \\
\hline 3 & 25 & - & 500 & 525 & - & 1000 & - & - & 5000 \\
\hline 4 & 188 & 375 & - & 563 & 1500 & - & - & - & 10500 \\
\hline 5 & 104 & 459 & - & 563 & 500 & 1251 & 834 & 209 & 11633 \\
\hline 6 & 13 & 363 & 750 & 1125 & 600 & - & - & - & 4200 \\
\hline 7 & - & - & 1250 & 1250 & - & 750 & 1000 & 1250 & 9000 \\
\hline 8 & 110 & - & 1250 & 1360 & 150 & - & 500 & - & 1800 \\
\hline 9 & 200 & - & 1250 & 1450 & 800 & - & - & - & 5600 \\
\hline 10 & 132 & 1315 & - & 1447 & 631 & 526 & 526 & - & 7836 \\
\hline 11 & 555 & - & 1250 & 1805 & 600 & - & - & - & 4200 \\
\hline
\end{tabular}


The results of the analysis show that the number of tree plants has a negative correlation with the production of medicinal plants with a value of $r=$ -0.079 as well as the number of tree plants has a negative correlation with income with a value of $r=-0.218$. This study shows that increasing the number of perennials planted on community arable land in the MHSNP area will reduce medicinal plants' production. The more the number of hard plants, the medicinal plants found in arable land will be more shaded, resulting in reduced light intensity so that medicinal plants' production will decrease.

This shows that by increasing the number of perennials planted so that the production of medicinal plants decreases, the income of medicinal plants will also decrease. Correlation coefficient values that indicate the relationship between the production of medicinal plants with the income of medicinal plants. The results of the analysis are strong and positive relationships between the production of medicinal plants with the income of medicinal plants with a value of $r=0.839$. An increase follows the increased production of medicinal plants in the income of medicinal plants. The number of trees planted did not significantly correlate with medicinal plant production, nor did the number of trees correlate significantly with income from medicinal plants $(\mathrm{p}<0.05)$.

\subsubsection{The economic benefits of medicinal plants}

The area of MHSNP in Gunung Malang Village is 533 ha with an average land-use area of $0.58 \mathrm{ha} /$ person. When referring to the analysis results, the income of respondents from one type of planted business is the cardamom. The cardamom planted under tree stands 563 trees/ha produces $1500 \mathrm{~kg}$ of cardamom/ha with an income of Rp 10,500,000 per ha by referring to cardamom price $7,000 / \mathrm{kg}$. Then the estimated value of the cardamom plant's economy found in the MHSNP area in Gunung Malang Village with an area of 533 ha, amounting to Rp5,596,500,000/year. If the four types of plants cultivated with the number of trees are 563 trees/ha, then the estimated economic value of cardamom plants is $\mathrm{Rp} 1,865,500,000$, ginger is $\mathrm{Rp} 2,667,132,000$, turmeric is $\mathrm{Rp} 666,783,000$, and galangal is $\mathrm{Rp} 334,191,000$ with reference to prices ginger

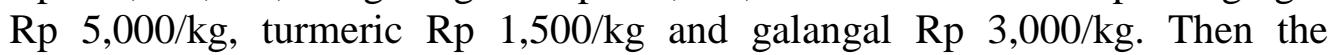
economic estimation value of four medicinal plants in the MHSNP area in Gunung Malang Resort Village Cimantaja was Rp 5,533,606,000/year.

\subsubsection{Green Marketing}

Green marketing emerged due to increasing environmental groups who are environmentally conscious in their daily consumption behavior (ecologically conscious consumer behavior). As an impact of increasing consumer awareness of the impact of consumption on the environment, there is an increasing demand for green products [36]. Green marketing can also be 
defined as marketing activities with a responsibility to the environment, which is, to a minimum, harm the environment. So it can be explained that the purpose of green marketing is to produce a product by taking into account environmental factors, monitoring the impact of the economy, and responding to government regulations on the environment [37]. These advantages are often approached through life-cycle analysis (LCA) that measures the environment's effect on products at all stages of the product life cycle [38].

Green marketing implements a proactive strategy to meet the market by providing products or services that are environmentally friendly or both to reduce or minimize adverse impacts on the environment. Seeing the importance of green marketing in basic life can be stated that green marketing is a strategy that must be done to save the earth and the welfare of future generations. Respondents choose to use green their systems because green products are profitable. Pricing of green marketing is important and considering the fact that they support environmental friendliness so the value can be added to the product for changing its appearance, functionality and through customization.

The concept of green marketing by utilizing limited resources efficiently and effectively. Internal and external components also support the concept of green marketing. Respondents as farmers producing medicinal plants are internal components as producers who sell their crops directly to intermediaries, which are external green marketing components. Respondents are very concerned about environmental factors in crop production by conducting sustainable harvesting techniques at the right time and age of the plant so that the management of natural resource utilization can be optimized by considering current and future needs.

\section{Conclusion}

Characteristics of individual respondents are relatively homogeneous; most of them are of productive age with a relatively low level of formal education and work as farmers. The average respondent's income is below the regional minimum wage (UMR) of West Java Province, Sukabumi Regency.

Most people who cultivate land in the MHSNP area plant cardamom, ginger, and turmeric with agroforestry patterns understand combined with various types of forestry plants, MPTS, and plantation crops. The advantage of this cropping pattern is that the forest is maintained and plays a role in ecological aspects and economic and socio-cultural aspects. The ecological aspect is a forest ecosystem and has a function in supporting the sustainability of the ecosystem. From an economic aspect, it can become one source of income for 
the community around the forest. From the socio-cultural aspect, the community was involved in the utilization of NTFPs for medicinal plants.

Respondents' income from medicinal plants can support the household economy of the respondent. The income of respondents from cardamom is higher compared to other types of medicinal plants. The estimated value of the cardamom plant in the MHSNP area in Gunung Malang Resort Cimantaja Village is Rp 5,596,500,000/year.

\section{Acknowledgments}

The authors would like to thank to the management of the Center for Forest Research and Development who have funded and facilitated the research implementation. Acknowledgments also the authors convey to the Sub-Ofice Head and all Mount Halimun Salak National Park staff who have facilitated and permitted the implementation of this research activity. The authors also thank all those who have helped in the implementation of this research. 


\section{References}

[1] Kurniawan W, Kusuma C, Basuni S, Munandar A, Kholil. 2013. Analisis konflik pemanfaatan lahan di kawasan Taman Nasional Gunung Halimun Salak. Jurnal Pengelolaan Sumberdaya Alam dan Lingkungan 3 (1): 23-30

[2] Prayitno D.E. 2020. Kemitraan konservasi sebagai upaya penyelesaian konflik tenurial dalam pengelolaan kawasan konservasi di Indonesa. Jurnal Hukum Lingkungan Indonesia 6 (2): 184 - 209

[3] Dunggio I, Gunawan H. 2009. Telaah Sejarah Kebijakan Pengelolaan Taman Nasional Di Indonesia. Jurnal Analisis Kebijakan Kehutanan 6(1): 43 - 56.

[4] Hastari B, Yulianti R. 2018. Pemanfaatan dan nilai ekonomi hasil hutan bukan kayu di KPHL KapuasKahayan. Jurnal Hutan Tropis 6 (2): 145-153

[5] Annafiandini M. 2016. Nilai Manfaat Taman Nasional Baluran Bagi Masyarakat Desa Watukebo Kabupaten Banyuwangi Jawa Timur. [Skripsi]. Fakultas Kehutanan, Institut Pertanian Bogor. Bogor.

[6] Ulfa M, Albayudi, dan Sirait M. 2019. Jenis dan nilai hasil hutan bukan kayu terhadap Suku Anak Dalam di Taman Nasional Bukit Duabelas. Jurnal Silva Tropika 3(1): 132-142

[7] Adalina Y. 2017. Pemanfaatan hasil hutan bukan kayu di Taman Nasional Gunung Halimun Salak oleh masyarakat Kasepuhan Sinar Resmi, Jawa Barat. Prosiding Seminar Nasional Masyarakat Biodiversitas Indonesia 3 (1): 75-80

[8] Nugroho, A. C., T. M. Frans, R. P. Kainde, dan H. D.Walangitan. 2015. Kontribusi hasilhutan bukan kayu bagi masyarakat di sekitar kawasan hutan. Jurnal Cocos (5):12p.

[9] Ahenkan A, Boon E. 2011. Non-Timber Forest Product (NTFPs): Clearing the Confusion in Semantics. Journal of Human Ecology 33 (1): 1 - 9

[10] Indrasari D, Wulandari C, Bintoro A. 2017. Pengembangan potensi hasil hutan bukan kayu oleh kelompok Sadar Hutan Lestari Wana agung di Register 22 Way Waya Kabupaten Lampung Tengah. Jurnal Sylva Lestari 5 (1): 81-91

[11] Junaedi E, Maryani R. 2013. Pengaruh dinamika spasial sosial ekonomi pada suatu Lanskap Daerah Aliran Sungai (DAS) Terhadap Keberadaan Lanskap Hutan (Studi kasus pada DAS Citanduy Hulu dan DAS Ciseel, Jawa Barat. Jurnal Penelitian Sosial Ekonomi Kehutanan 10 (2): 122-139

[12] Hendri, Hakim L, Batoro J. 2018. Kearifan local masyarakat sebagai upaya konservasi hutan Pelawan di Kabupaten Bangka Tengah, Bangka Belitung. Jurnal Ilmu Lingkungan 6 (1): 49-57

[13] Peraturan Menteri Kehutanan Republik Indonesia Nomor P19/Menhut-II/2019 Tentang Strategi Pengembangan Hasil Hutan Bukan Kayu Nasional.

[14] Schimdt F.H and Ferguson J.H.A. 1951. Rain fall type based on wet and dry period ratios for Indonesia with Western New Guinea. Verh. No 42. Direktorat Metereologi dan Geofisika Jakarta.

[15] [BTNGHS] Balai Taman Nasional Gunung Halimun Salak. 2011. Laporan Tahunan Balai Taman Nasional Gunung Halimun Salak tahun 2010. Kabandungan (ID): BTNGHS

[16] Soerianegara I, Indrawan. 2002. Ekologi Hutan Indonesia. Jurusan Manajemen Hutan, Fakultas Kehutanan IPB. Bogor.

[17] Adiprasetyo T, Eriyanto, Noor E. \& Sofyan F. (2009). Sikap masyarakat lokal terhadap konservasi taman nasional sebagai pendukung keputusan dalam pengelolaan Taman Nasional Kerinci Seblat. Jurnal Bumi Lestari 9 (2): 173-186. Universitas Udayana. Bali.

[18] Adalina Y, Nurrochmat D.R., Darusman D, Sundawati 1. 2015. Kondisi sosial ekonomi masyarakat di sekitar kawasan Taman Nasional Gunung Halimun Salak. Jurnal rehabilitasi Hutan dan Konservasi Alam 12(2): 105-118 
[19] Mantra I.B. 2000. Demografi umum. Pustaka Pelajar. Yogyakarta. 396 hal.

[20] Waluyo E.A., Ulya, N.A., dan Martin, E. 2010. Perencanaan sosial dalam rangka pengem- bangan hutan rakyat di Sumatera Selatan. Jurnal Penelitian Hutan dan Konservasi Alam 8 (3): 271-280. Puslibang Konservasi dan Rehabilitasi. Bogor.

[21] Rinawati, R. (2012). Modal sosial masyarakat dalam pembangunan hutan rakyat di Sub Das Cisadane Hulu (kasus di areal DAS Mikro Sub DAS Cisadane Hulu) [tesis]. Program Pascasarjana, Institut Pertanian Bogor. Bogor. 170 hal.

[22] Ristianasari, Muljono, P., \& Gani, D.S. 2003. Dampak program pemberdayaan model desa konservasi terhadap kemandirian masyarakat: kasus di Taman Nasional Bukit Barisan Selatan Lampung. Jurnal Penelitian Sosial dan Ekonomi 10 (3):173-185. Puslitbang Sosial Ekonomi dan Kebijakan Kehutanan. Bogor.

[23] Hamid R, Zulkarnaini, \& Saam, Z. 2011. Analisis sosial ekonomi masyarakat desa hutan pasca kegiatan HPH PT Siak Raya Timber di Kabupaten Pelalawan, Provinsi Riau. Jurnal Ilmu Lingkungan 5 (2): 130-148. Program Studi Ilmu Lingkungan Universitas Riau. Pekan Baru.

[24] Mulyono, M.M.B. 2012. Modal sosial dalam pengelolaan kebun hutan (dukuh) di Keca- matan Karang Intan, Kabupaten Banjar, Provinsi Kalimantan Selatan [tesis]. Program Pascasarjana, Institut Pertanian Bogor. Bogor. 149 hal.

[25] Pujowati P, Arifin A.S, Mugnisjah W.Q. 2010. Analisis Sosial Ekonomi Masyarakat di Daerah Aliran Sungai Karang Mumus Dalam Rencana Pengelolaan Lanskap Agroforesty. Jurnal Agro Ekonomi Kehutanan EPP 7 (1): 8 - 13.

[26] Kadir A, Awang S. A, Purwanto, R.H, \& Poedjirahajoe E. 2012. Analisis kondisi sosial ekonomi masyarakat sekitar Taman Nasional Batimurung Bulusaraung, Provinsi Sulawesi Selatan. Jurnal Manusia Dan Lingkungan 19 (1): 1-11. Pusat Studi Lingkungan Hidup Universitas Gadjah Mada. Yogyakarta.

[27] Subarna, T. (2011). Faktor yang mempengaruhi masyarakat menggarap lahan di hutan lindung: studi kasus di Kabupaten Garut, Jawa Barat. Jurnal Penelitian Sosial Ekonomi Kehutanan 8 (4): 265-275. Puslitbang Sosial Ekonomi dan Kebijakan Kehutanan. Bogor.

[28] Gunawan H, Bismark M. \& Krisnawati H. 2013. Kajian sosial ekonomi masyarakat sekitar sebagai dasar penetapan tipe pe- nyangga Taman Nasional Gunung Merbabu, Jawa Tengah. Jurnal Penelitian Hutan dan Konservasi Alam 10 (2): 103-117. Puslitbang Konservasi dan Rehabilitasi. Bogor.

[29] Supranto J. 2000. Statistik, teori dan aplikasi. Tulus S dan Ali S, Edidor. Edisi 6 Cetakan pertama. Erlangga. Jakarta. 384 hal.

[30] Adalina Y, Nurrochmat D.R., Darusman D, Sundawati 1. 2014. Harvesting of non-timber forest products by the local communities in Mount Halimun -Salak National Park, West Java, Indonesia. Jurnal Manajemen Hutan Tanaman 20 (2): 103-111. DOI: 10.7226/jtfm.20.2.103

[31] van Wilgen BW, Richardson DM. 2012. Three centuries of managing introduced conifers in South Africa: benefits, impact, changing perception and conflict resolution. Journal of Environmental Management 106:56-68. http://dx.doi.org/10.1016/j.jenvman.2012.03.052.

[32] Rusdiana O, Amalia R.F. 2012. Land suitability of Pinus merkusii Jungh et de Vriese on ex-standing area of Tectona grandis Linn. F. Jurnal Silvikultur Tropika 3(3):174-181.

[33] Diniyati D, Fauziyah E, Widyaningsih T.S. 2014. Upaya peningkatan kualitas kapulaga dan produktivitas tanaman kapulaga sebagai tanaman sela di hutan rakyat. Jurnal Penelitian Agroforestry 7 (1): 21-34.

[34] Diniyati D dan Achmad B. 2015. Kontribusi pendapatan hasil hutan bukan kayu pada usaha hutan rakyat pola agroforestry di Kabupaten Tasikmalaya. Jurnal Ilmu Kehutanan 9 (1): 23-31 
[35] Achmad B. 2016. Pola tanam dan pendapatan petani hutan rakyat di Region Atas Kabupaten Ciamis : Jurnal Kawistara 6 (3) : 225-324

[36] Ekowati T, Saputra M.H. 2015. Aplikasi strategi green marketing dengan studi kasus beberapa perusahaan di Indonesia. Jurnal Manajemen dan Bisnis 11(1): 17-44

[37] Papadas K.K, Avlonitis G.J, Carrigan M. 2017. Green marketing orientation: Copceptualization, scale development and validation. Journal of Business Research, 80: 236-246

[38] Sutrisno W. 2014. Green marketing dan implikasinya terhadap sustainable development di era globalisasi, kajian terhadap strategi pemasaran yang berkelanjutan. Business \& Management Journal 11 (2): 151-162 